\title{
BACTERIAL AND YEAST COUNTS IN BRAZILIAN COMMODITIES AND SPICES
}

\author{
Francisco das Chagas Oliveira Freire ${ }^{1 *}$; Lisa Offord $^{2}$ \\ ${ }^{1}$ Embrapa Agroindústria Tropical, Laboratório de Fitopatologia, Fortaleza, CE, Brasil. ${ }^{2} \mathrm{CABI}$ Bioscience, \\ UK Centre, Egham, England.
}

Submitted: May 31, 2002; Returned to authors for corrections: November 22, 2001; Approved: May 13, 2002

\section{SHORT COMMUNICATION}

\begin{abstract}
A total of thirteen genera of bacteria and two genera of yeasts were detected in surface sterilized and unsterilized Brazilian commodities and spices such as cashew kernels, Brazil nut kernels, black and white pepper. The genus Bacillus with eight species was by far the most common. The yeasts isolated were Pichia sp., P. guillermondii and Rhodotorula sp. Bacillus cereus, Salmonella typhimurium and Staphylococcus aureus were detected in cashew and Brazil nut kernels.
\end{abstract}

Key words: cashew kernels, Brazil nut kernels, black and white pepper, microbiology.

Commodities such as cashew kernels, Brazil nut kernels and spices as black and white pepper are subjected to microbial contamination at various stages. The traditional methods of harvesting and preparations of these products result in heavy contamination. Growth of bacteria and yeasts may take place if the environmental conditions are damp, when equipment and workers may contribute to increase the levels of contamination.

Although being an excellent substrate for microorganisms growth, occurrence of bacterial infection on cashew kernels has rarely been reported. Studies conducted in South Africa (20) revealed light contamination of processed and nonprocessed cashew kernels by Bacillus spp. As for Brazil nut kernels, bacteria associated with decaying was first reported in 1921 (17). Mesophile bacterial counts on roast and salted Brazil nut kernels ranged from $5.3 \times 10^{3}$ to $1.2 \times 10^{4} \mathrm{cfu} / \mathrm{g}$ during storage period. Yeasts occurred in very low counts. The authors, however, did not identify bacteria (16). Concerning to black pepper, which accounts for some $35 \%$ of the world trade in ground spice, counts are by far the highest among the spices most used. Total number of bacteria ranging from $8.3 \times 10^{6}$ to $7.09 \times 10^{8} \mathrm{cfu} / \mathrm{g}$ (mean $1.9 \times 10^{8}$ ) has been confirmed (5). Other workers have also found high levels of bacterial contamination on black pepper, although yeast populations had always been low $(6,12,13,14)$. White pepper, to a lesser extent, can also be a source of contamination (2). Bacteria such as Bacillus spp., Escherichia freundii, E. coli, Klebsiella sp., Serratia sp., Staphylococcus spp. and Streptococcus spp. have been identified on black and white pepper. A comprehensive review on spices microbiology has been provided (7).

In the present paper an attempt has been made to survey the species of bacteria and yeasts on cashew nuts, Brazil nuts, black and white pepper imported from Brazilian producers.

A total of 4 samples of black pepper (500 g each), 4 samples of white pepper ( $500 \mathrm{~g}$ each) and 2 samples of Brazil nut kernels ( $2 \mathrm{~kg}$ each) were purchased from two retail suppliers in Belem city (State of Pará), in the Brazilian Amazonian Region. Ten kilograms of cashew kernels of common type $(5 \mathrm{~kg})$ and dwarf type $(5 \mathrm{~kg})$ were obtained from farmers of the State of Ceará (Pacajus county) in the Brazilian Northeastern Region. All samples were brought to CABI Bioscience (Egham, England) where commodities and spices were separated into visually healthy and infected. Sub-samples of $1 \mathrm{~g}$ (for black and white pepper) and $3 \mathrm{~g}$ (for common and dwarf cashew types), healthy and infected, were taken for microbiological analysis.

\footnotetext{
* Corresponding author. Mailing Address: Embrapa Agroindústria Tropical, Laboratório de Fitopatologia, Rua Dra Sara Mesquita, 2270, Planalto Pici.
} 60511-110, Fortaleza, CE, Brasil. E-mail: freire@cnpat.embrapa.br 
The first batch of samples was placed in sterile universal vials and covered with $30 \%$ hydrogen peroxide for 5 minutes. After removal from $\mathrm{H}_{2} \mathrm{O}_{2}$ samples were rinsed in sterile distilled water and ground up with pestle and mortar in $5 \mathrm{ml}$ of sterilized distilled water. Progressive dilutions $\left(10^{-1}, 10^{-2}\right.$ and $\left.10^{-3}\right)$ were prepared and $0.1 \mathrm{ml}$ of each was spread onto the nutrient agar surface in five $9 \mathrm{~cm}$ diameter disposable Petri dishes. Plates were kept at laboratory temperature $\left(18^{\circ} \mathrm{C}\right.$ to $\left.25^{\circ} \mathrm{C}\right)$ and colonies counted after 5 days. For the second batch samples were ground up without previous surface sterilization and dilutions were up to $10^{-5}$.

Fresh bacterial and yeast colonies $(24-48 \mathrm{~h}$ old $)$ were suspended in sterilized distilled water and processed in a Hewlett Packard 5890 Series II Gas Chromatograph for the extraction of the fatty acids. The organisms (bacteria/yeast) were identified using the MIDI microbial identification system where fatty acids profiles are compared with a database. The whole process from initial sub-culture to final identification was completed in $72 \mathrm{~h}$.

The results of microbial load in cashew and Brazil nut kernels, in black and white pepper, with and without surface sterilization, are given in Tables 1 and 2, respectively. A total of thirteen

Table 1. Bacterial and yeast counts of surface sterilized Brazilian commodities and spices.

\begin{tabular}{lll}
\hline \multicolumn{1}{c}{ Source } & \multicolumn{1}{c}{ Organisms } & cfu/samples \\
\hline Common cashew & Bacillus macerans & $0.20 \times 10^{2}$ \\
(healthy) & B. pumilus & $0.40 \times 10^{2}$ \\
Common cashew & B. macerans & $0.10 \times 10^{2}$ \\
(infected) & B pumilus & $0.15 \times 10^{2}$ \\
& Micrococcus luteus & $0.10 \times 10^{2}$ \\
Dwarf cashew & B. macerans & $0.15 \times 10^{2}$ \\
(healthy) & B. pumilus & $0.70 \times 10^{2}$ \\
& Gordona bronchialis & $1.2 \times 10^{2}$ \\
& Staphylococcus aureus & $1.7 \times 10^{2}$ \\
& *Pichia guillermondii & $3.2 \times 10^{2}$ \\
Dwarf cashew & B. macerans & $0.14 \times 10^{2}$ \\
(infected) & B. pumilus & $0.70 \times 10^{2}$ \\
& B. spaericus & $0.16 \times 10^{2}$ \\
& S. aureus & $0.20 \times 10^{2}$ \\
Black pepper & B. macerans & $2.1 \times 10^{3}$ \\
& B. pumilus & $2.9 \times 10^{3}$ \\
White pepper & B. macerans & $0.32 \times 10^{3}$ \\
& B. pumilus & $0.53 \times 10^{3}$ \\
Brazil nut & B. macerans & $0.1 \times 10^{2}$ \\
& B. pumilis & $0.1 \times 10^{2}$ \\
& *. aureus & $0.64 \times 10^{2}$ \\
& & $9.14 \times 10^{2}$ \\
\hline \multirow{2}{*}{ (ichia sp. } &
\end{tabular}

* yeasts.
Table 2. Bacterial and yeast counts of Brazilian commodities and spices without sterilization.

\begin{tabular}{|c|c|c|}
\hline Source & Organisms & cfu/samples \\
\hline $\begin{array}{l}\text { Common cashew } \\
\text { (healthy) }\end{array}$ & $\begin{array}{l}\text { Bacillus macerans } \\
\text { B. megaterium } \\
\text { B. mycoides } \\
\text { Enterobacter sakazakii } \\
\text { Klebsiella pneumoniae } \\
\text { Micrococcus luteus } \\
\text { Xanthomonas } \\
\text { maltophilia }\end{array}$ & $\begin{array}{l}0.40 \times 10^{2} \\
0.25 \times 10^{2} \\
0.15 \times 10^{2} \\
0.38 \times 10^{3} \\
0.60 \times 10^{2} \\
0.15 \times 10^{2} \\
0.14 \times 10^{2}\end{array}$ \\
\hline $\begin{array}{l}\text { Common cashew } \\
\text { (infected) }\end{array}$ & $\begin{array}{l}\text { Acinetobacter baumannii } \\
\text { B. cereus } \\
\text { B. macerans } \\
\text { B. subtilis } \\
\text { E. cloacae } \\
\text { E. sakazakii } \\
\text { M. luteus } \\
\text { Rhodobacter capsulatus } \\
\text { Staphylococcus hominis } \\
\text { X. maltophilia }\end{array}$ & $\begin{array}{l}0.10 \times 10^{2} \\
0.17 \times 10^{2} \\
0.13 \times 10^{2} \\
0.12 \times 10^{2} \\
0.08 \times 10^{2} \\
0.21 \times 10^{2} \\
0.19 \times 10^{2} \\
0.10 \times 10^{2} \\
0.10 \times 10^{2} \\
0.10 \times 10^{2}\end{array}$ \\
\hline $\begin{array}{l}\text { Dwarf cashew } \\
\text { (healthy) }\end{array}$ & $\begin{array}{l}\text { B. macerans } \\
\text { B. megaterium } \\
\text { B. mycoides } \\
\text { E. sakazakii }\end{array}$ & $\begin{array}{l}0.20 \times 10^{2} \\
0.09 \times 10^{2} \\
0.12 \times 10^{2} \\
0.10 \times 10^{2}\end{array}$ \\
\hline $\begin{array}{l}\text { Dwarf } \\
\text { cashew(infected) }\end{array}$ & $\begin{array}{l}\text { B. cereus } \\
\text { B. macerans } \\
\text { B. mycoides } \\
\text { B. pumilis } \\
\text { E. sakazakii } \\
\text { K. pneumoniae }\end{array}$ & $\begin{array}{l}0.18 \times 10^{2} \\
0.10 \times 10^{2} \\
0.12 \times 10^{2} \\
0.20 \times 10^{2} \\
0.16 \times 10^{2} \\
\end{array}$ \\
\hline Black pepper & $\begin{array}{l}\text { B. alvei } \\
\text { B. pumilis } \\
\text { B. subtilis } \\
\text { Clavibacter } \\
\text { michiganense } \\
\text { Erwinia herbicola } \\
\text { M. kristinae }\end{array}$ & $\begin{array}{r}69.6 \times 10^{3} \\
36.8 \times 10^{3} \\
13.0 \times 10^{3} \\
1.8 \times 10^{3} \\
010 \times 10^{2} \\
0.30 \times 10^{2} \\
\end{array}$ \\
\hline White pepper & $\begin{array}{l}\text { B. macerans } \\
\text { B. pumilis } \\
\text { B. sphaericus } \\
\text { B. thuringiensis } \\
\text { M. luteus }\end{array}$ & $\begin{array}{l}0.15 \times 10^{2} \\
0.80 \times 10^{2} \\
0.10 \times 10^{2} \\
0.12 \times 10^{2} \\
0.17 \times 10^{2}\end{array}$ \\
\hline Brazil nut & $\begin{array}{l}\text { Acinetobacter baumannii } \\
\text { B. cereus } \\
\text { B. macerans } \\
\text { B. subtilis } \\
\text { Escherichia coli } \\
\text { E. sakazakii } \\
\text { *Pichia sp. } \\
\text { Rothayibacter tritici } \\
\text { *Rhodotorula sp. }\end{array}$ & $\begin{array}{r}2.2 \times 10^{3} \\
4.0 \times 10^{3} \\
5.1 \times 10^{3} \\
3.2 \times 10^{2} \\
1.3 \times 10^{2} \\
4.2 \times 10^{2} \\
6.4 \times 10^{4} \\
1.1 \times 10^{2} \\
10.7 \times 10^{4}\end{array}$ \\
\hline
\end{tabular}

* yeasts. 
genera of bacteria and two genera of yeasts were encountered among the microorganisms isolated. The genus Bacillus with eight species was by far the most common. The yeasts Pichia guillermondii, Pichia sp. and Rhodotorula sp. were present in higher populations, compared to bacteria. Yeasts were detected in cashew and Brazil nut kernels.

Among the commodities and spices surface sterilized, healthy dwarf cashew kernels showed the highest variety of microorganisms isolated. The higher populations, however, was detected in black pepper. When samples were examined without surface sterilization Brazil nut kernels yielded greater variety of species and the highest population of yeasts. Black pepper had the highest bacterial contamination. Erwinia herbicola was the only bacteria isolated which can behave as plant pathogen. B. cereus and Staphylococcus aureus have been reported as food poisoning agents.

As was expected, samples without surface sterilization yielded higher numbers of bacterial and yeast colonies as well as greater variety of microorganisms species. Bacillus spp. were the most common bacteria isolated, being present in all samples either with or without sterilization. Among the species isolated only E. herbicola and Clavibacter michiganense have been recognized as a plant pathogen. X. maltophilia, although belonging to a genus which encompasses some plant pathogens is actually a saprophyte. Most of the species isolated are ubiquitous saprophytes, commonly found in soil, water and on plant surfaces (3). Their presence in the commodities and spices examined revealed mainly contamination due to inadequate handling and storage.

Spices are known to be heavily contaminated with microorganisms. Ground black pepper may carry as many as $10^{8}$ bacteria/g. White pepper, to a lesser extent, may also be infected $(2,5,6,11)$. Most bacteria present in spices are aerobic sporeformer. Baxter and Holzapfel (2) found that approximately $90 \%$ of colonies in viable counts were Bacillus spp. In the present study we have obtained similar results, with six species of Bacillus being identified. Our counts, however, are far lower compared to the workers above. Among the species we isolated only few of them have been associated with food poisoning. Indeed, B. cereus has been recognized as the etiological agent of food poisoning outbreaks in Europe as far back as 1906 (8). In USA and United Kingdom foodborne illness due to this species has been reported between 1968 and $1975(18,19)$ According to Silliker (15), black pepper contaminated with aerobic spore formers enormously increased the microbial count of sausage. Aerobic spore formers have also been detected in white pepper powder (9). Coliforms and faecal streptococci were present in significant numbers in black and white pepper $(2,13)$. We did not isolate faecal species from our black and white pepper samples but Salmonella has been found in black pepper produced in the Brazilian Amazonian Region (Dr. Maria L. Duarte, personal communication). Interestingly no yeasts were detected in our black and white pepper samples. This may have occurred due to the inhibitory effects of essential oils present in these spices. Guarino (10) noted that yeasts were either entirely absent or present only in insignificant numbers in spices. Working with Indian spices Krishnaswamy et al. (13) identified the species Candida huminicola, C. parapsilosis and C. tropicalis.

As far as cashew kernels are concerned the only report on bacterial occurrence was the isolation of Bacillus spp.(20). In our study Bacillus spp. were too the most common organisms found but eight other different genera of bacteria and the yeast $P$. guillermondii were also detected. Among them a considerable number of coliforms such as E. cloacae, E. sakazakii and $K$. pneumoniae were found. Species associated with food poisoning as $B$. cereus and $S$. aureus occurred commonly on the commodity. As no case of food poisoning with cashew kernels have ever been reported, the possible explanation is that strains occurring on cashew kernels are mainly saprophytic, thus unable to produce enterotoxins, or because they have always been isolated in low numbers. Besides, the kernels examined were fresh and non-processed. As the processing involves heating and they are usually salted, these stages would be sufficient to kill the bacteria. The only yeast identified, $P$. guillermondii, is harmless and may be using the kernels as an occasional food source.

Concerning Brazil nut kernels, as far as we are aware, there has been no reports on bacterial or yeast identification. Although the presence of bacteria in decaying Brazil nut had been detected since 1921(17), no attempt was made to identify them. In Brazil a microbiological evaluation of roasted and salted Brazil nut kernels stored at room temperature revealed the presence of low population of unidentified mesophilic, thermophilic, proteolytic and lipolytic bacteria (16). Counts of the yeasts Pichia sp. and Rodotorula sp. were higher in Brazil nut compared to cashew kernel samples. Counts of bacteria such as Bacillus spp., E. coli and $S$. typhimurium were not high but these findings indicates the unsuitable conditions the nuts were handled during processing. The samples used in the present study were purchased already shelled. This obviously exposed them to manual contact which may have facilitated their microbial contamination. It is well known that the hard shell can protect them from external invaders during storage and shipment $(1,4)$.

Despite the presence of $B$. cereus, S. typhimurium and $S$. aureus in cashew and Brazil nut kernels, there is no reason for concern about the possibility of these commodities being a source of pathogenic bacteria, provided the processed kernels are properly packed and stored. Most of these strains are saprobes, thus unable to produce enterotoxins. Probably the strains we isolated are typically saprophytic, posing no threat to consumers' health.

As for black and white pepper the results of this investigation show that no organism posing a public health hazard was found. 
The common occurrence of populations of Bacillus spp., $C$. michiganense, E. herbicola and Micrococcus spp. may also be expected since hundreds of small farmers with diverse growing and harvesting techniques are involved in the production of these spices. It must be pointed out, however, that spices such as black and white pepper may be a source of contamination if they are allowed to harbour sufficient population of toxigenic bacteria, mainly when incorporated into uncooked convenience foods. These microorganisms do not present a health hazard when spices are consumed in food which is cooked directly after addition of the spices. More recently major producing countries like Brazil are employing modern artificial drying equipment for commercial purpose. Such through-flow hot-air dryers can provide the market with pepper of better microbiological standard.

\section{ACKNOWLEDGEMENTS}

This research was supported by the Brazilian Council for Technological and Scientific Development (CNPq).We are grateful to Dr. Gerry Saddler and Dr. Zofia Lawrence at the CABI Bioscience (Egham, England) for useful comments on this manuscript.

\section{RESUMO}

\section{Bactérias e leveduras associadas a amêndoas de cajueiro, de castanha-do-Brasil $e$ à pimenta-do-reino preta e branca}

Um total de 13 gêneros de bactérias e 2 de leveduras foi detectado a partir de amêndoas de castanha de cajueiro, de amêndoas de castanha-do-Brasil e de pimenta-do-reino preta e branca produzidas no Brasil. O gênero bacteriano mais freqüentemente encontrado foi o Bacillus, com 8 espécies. As leveduras Pichia sp., P. guillermondii e Rhodotorula sp., isoladas somente a partir de amêndoas de cajueiro, apresentaram populações mais elevadas que as de bactérias. Bacillus cereus, Salmonella typhimurium e Staphylococcus aureus foram também detectadas em amêndoas de cajueiro e de castanha-do-Brasil.

Palavras-chave: população microbiana, amêndoas de cajueiro, castanha-do-Brasil, pimenta-do-reino, bactérias, leveduras.

\section{REFERENCES}

1. Ayerst, G.; Budd, D. Effect of moisture contents on the storage of Brazil nuts. J. Sci. Food Agric., 11: 390-396, 1960.

2. Baxter, R.; Holzapfel, W.H. A microbial investigation of selected spices, herbs and additives in South Africa. J. Food Sci., 47: 570$578,1982$.

3. Bergey's manual of determinative bacteriology. Buchnan, G.R.E.; Gibons, N.E. $8^{\text {th }}$ ed., Williams \& Wilkins, Baltimore, 1974, 1268p.

4. Castrillón, A.L.; Purchio, A. Fungos contaminantes e produtores de aflatoxinas em castanha do Pará. Acta Amaz., 18: 173-183, 1988.

5. Christensen, C.M.; Fanse, H.A.; Nelson, G.H.; Bates, F.; Mirocha, C.J. Microflora of black pepper and red pepper. Appl. Microbiol., 15: 622-626, 1967.

6. Flannigan, B.; Hui, S.C. The occurrence of aflatoxin-producing strains of Aspergillus flavus in the mould floras of ground spices. J. Appl. Bacteriol., 41: 411-418, 1976.

7. Flannigan, B.; Llewellyn, G.C. The microbiology and mycotoxicology of spices: a review. Biodeterioration 6: 273-279, 1986.

8. Goepfert, J.M.; Spira, W.M.; Kim, H.U. Bacillus cereus: food poisoning organism. A review. J. Milk Food Technol., 35: 213-227, 1972.

9. Goleitz, K. Bacteriological investigation of spices most frequently used in meat industry. Med. Vet., 23: 362-364, 1967.

10. Guarino, P.A. Microbiology of spices, herbs and related material. Proceedings $7^{\text {th }}$ Annual Symposium West New York State Institute of Food Technology, 16-18, 1972.

11. Julseth, R.M.; Deibel, R.H. Microbial profile of selected spices and herbs at import. J. Milk Food Technol., 37: 414-419, 1974.

12. Krishnaswamy, M.A.; Patel, J.D.; Parthasarathy, N. Enumeration of micro-organisms in spices and spice mixtures. J. Food Sci. Technol., 8: 191-194, 1971.

13. Krishnaswamy, M.A.; Patel, J.D.; Parthasarathy, N.; Nair, K.K.S. Some of the types of coliforms, aerobic mesophilic spore formers yeasts, and moulds present in spices. J. Plant Crops, 1 (Suppl.): 200-203, 1973

14. Schwab, A.H.; Harpestad, A.D.; Schwartzentruber, A.; Lanier, J.M.; Wentz, B.; Duran, A.P.; Barnard, R.J.; Read, R.B. Microbiological quality of some spices and herbs in retail markets. Appl. Environm. Microbiol., 44: 627-630, 1982.

15. Silliker, J.H. Total counts as indexes of food quality. In: Slanetz, L.W.; Chichester, C.; Gaufin, A.R.; Ordal, Z.J. (eds). Microbiological Quality of Foods. Academic Press, New York, 1963, p.102-113.

16. Souza, M.L.; Holanda, L.F.F.; Maia, G.A.; Júnior, J.C.G.; Teixeira, E.A.M. Caracterização microbiológica de amêndoa torrada e salgada de castanha-do-Brasil (Bertholletia excelsa H. B. K.). Ciência Agron., 18: 161-166, 1987.

17. Spencer, E.R. Decay of Brazil nuts. Bot. Gaz., 72: 265-292, 1921.

18. U.S. Department of Health, Education and Welfare. Bacillus cereus food poisoning - United Kingdom. Morbidity and Mortality Reports, 22: $348,1973$.

19. U.S. Department of Health, Education and Welfare. Bacillus cereus food poisoning. Morbidity and Mortality Reports, 24: 306, 1975 .

20. Wehner, F.C.; Rabie, C.J. The micro-organisms in nuts and dried fruits. Phytophylactica, 2: 165-170, 1970. 